\title{
Computer Modeling of Pumping Station with Unregulated Electric Drive
}

\author{
Shakhboz Dadabaev ${ }^{1, *}$, and Elena Gracheva ${ }^{2}$ \\ ${ }^{1}$ Department of Power Supply and Automation, Khujand Polytechnic Institute of the Tajik Technical University Named after Academician \\ M.S. Osimi, Khujand 735700, Tajikistan \\ ${ }^{2}$ Department Power supply of industrial enterprises Kazan State Energy University, Kazan 420066, Russian Federation t
}

\begin{abstract}
The results of the analysis of transient and technological processes of the irrigation pumping station of the first lift, taking into account the negative starting effects on the synchronous electric drive, are considered. The analysis and review of the ways of regulating the performance of the units of the irrigation pumping station of the first lift are made, and the main difficulties of the existing methods of regulating the pump supply are revealed. Computer simulation of starting modes of high-voltage synchronous electric motors with direct and soft start, where soft starter was used for soft start, was carried out. The simulation took into account the changes in the currents of all phases of the electric motor, the electromagnetic torque, the motor speed, the effective value of the current, as well as the static torque. The introduction of semiconductor soft starters for electric drives of high-power pumping units has been substantiated.
\end{abstract}

\section{Introduction}

In this article, the Asht cascade of pumping stations, which serves to irrigate the lands of the Asht district of the Republic of Tajikistan, was adopted as the object of study. The design capacity of the ANS-1 pumping station is 1.77 million $\mathrm{m} 3$ of water per day, but after the collapse of the USSR and the outbreak of the civil war in Tajikistan, the need for such large volumes of water decreased sharply. At the moment, only two of the 4 units operate at the ANS-1 pumping station and the total capacity is 0.88 million $\mathrm{m} 3$ of water per day [1]. Asht cascade of pumping stations is a unique project consisting of five elevations, 8 stations, 61 pumping units, pipelines with a length of $33621 \mathrm{~m}$ and a total design capacity of 107.5 MW. Significant electric power is consumed by the ANS-1 first lift pumping station [2].

In the ANS-1 engine room there are 4 synchronous electric motors of the VDS2-325/69-16 type, with the following technical data: $P_{\text {nom }}=8000 \mathrm{~kW}, U_{\text {nom }}=10 \mathrm{kV}$, $\mathrm{n}_{\text {nom }}=375 \mathrm{rpm}$, efficiency $90 \%$. Vertical centrifugal pumps of type $1200 \mathrm{~V}-6.3 / 100-\mathrm{A}(52 \mathrm{~V}-11)$ have the following characteristics: $\mathrm{Q}=22600 \mathrm{~m}^{3} / \mathrm{h}, \mathrm{H}=88 \mathrm{~m}$, efficiency $88 \%, \mathrm{n}_{\text {nom }}=375 \mathrm{rpm}$, impeller diameter 2200 $\mathrm{mm}[3]$.

\section{Methodology for modeling}

Water enters the pump impellers from the Syr Darya river with a pressure of $5 \mathrm{~m}$, and the pumps are started only with an open gate valve. After the pump unit, water with a pressure of $88 \mathrm{~m}$ enters steel pipes with a diameter of $2.1 \mathrm{~m}$. In this way, two steel pipes $1142 \mathrm{~m}$ long are transport to the second stage water reservoir. Then water is taken from the reservoir by pumping stations of the 2nd stage.

For the purpose of further research and mathematical description of the ANS-1 technological processes, an ANS-1 technological scheme has been created, which is shown in Figure 1 [3, 4].

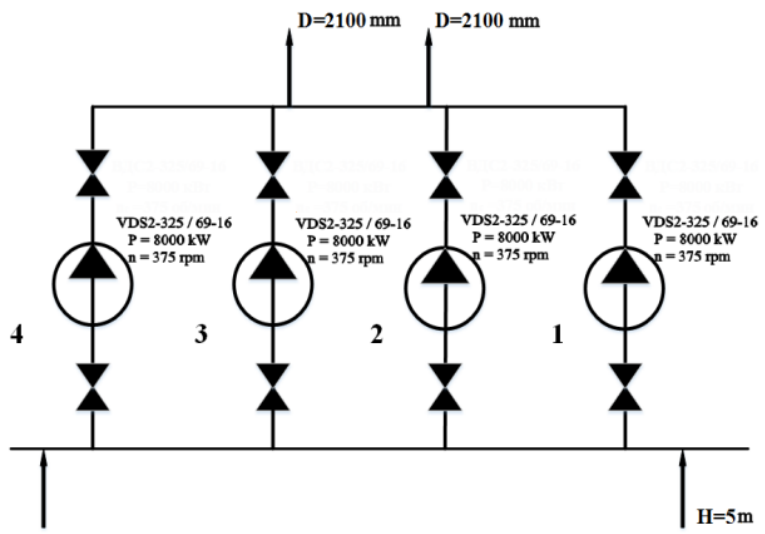

Fig. 1.The technological scheme of the irrigation pump station ANS-1.

For the mathematical description of the technological processes of the pumping station ANS-1, it is necessary to create a structural scheme of this object, which in turn requires the preparation of equations of the mathematical model $[5,6]$.

The operation of an unregulated pump can be described by the following equation:

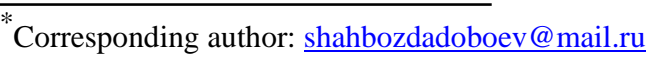




$$
H=H_{0}-R_{B H} Q^{2},
$$

where $R_{B H}$ is the internal resistance of the pump.

Taking into account additional resistances $R_{l}$ and $R_{2}$, we compose the equation:

$$
H^{\prime}=H_{0}-\left(R_{B H}+R_{2}+R_{3}\right) Q^{2}=H_{0}-R_{\Sigma} Q^{2},
$$

where $H^{\prime}$ is pressure in the pipeline; $H_{0}$ is pump pressure at $H_{0}=0$, which can be taken from $Q-H$ pump characteristics.

As a result, a structural scheme of the pumping station of the first stage was compiled in accordance with equation 2, which is shown in Figure 2, block 1 .

The joint work of 4 non-regulated pumps can be expressed by the following equation:

$$
Q_{\Sigma}=Q_{1}+Q_{2}+Q_{3}+Q_{4}=4 \sqrt{\frac{H_{0}-H^{\prime}}{R^{2} \Sigma}}
$$

The volume of incoming water into the reservoir $(\mathbb{P})$ of pump station second stage from ANS-1 can be taken:

$$
Q_{P}=Q_{\Sigma}
$$

where $Q_{\Sigma}$ is total pumping station water supply.

The replenishment of the reservoir of the second stage can be described by the following equation [7]:

$$
\Delta h_{P}=\frac{Q_{P}-Q_{P A}}{S_{P}} \cdot t,
$$

where $Q_{P}$ is volume of incoming water to the reservoir; $Q_{P A}$ is water supply to the consumer; $S_{P}$ is square of reservoir

Equation 5 in integral form will be of the next form:

$$
\Delta h_{P}=\frac{1}{S_{P}} \int\left(Q_{P}-Q_{P A}\right) d t .
$$

Equation 5 in operator form will have this form:

$$
\Delta h_{P}(p)=\frac{Q_{P}-Q_{P A}}{S_{P} \cdot p} .
$$

In accordance with equation 7 , a structural scheme of the reservoir $(\mathrm{P})$ was compiled (see to the Figure 2, block 2). As a result, a basic structural diagram of the irrigation pump station was compiled, which is presented in Figure 2 [3,8].

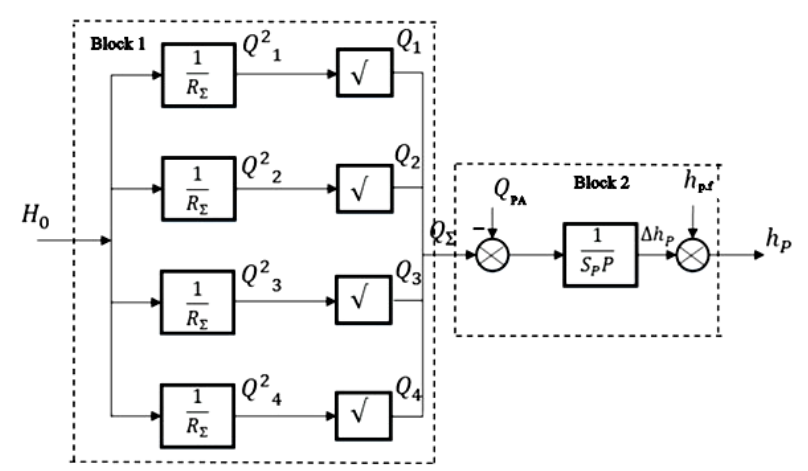

Fig. 2. The structural scheme of the irrigation station ANS-1.

This model will be the basis for the study of various methods of regulating the pumping units of the pumping station of the first stage.The development of a mathematical model and the analysis of the methods for regulating the supply of ANS-1 pumping units have shown that the introduction and use of controlled electric drives has a number of advantages and are very effective compared to non-controlled electric drives. Due to the soft starts of the electric motor, the technical resource and the service life of the electrical equipment will increase. As practice has shown at other facilities, the estimated energy savings when introducing a controlled electric drive is about 15 to $25 \%[10,11]$.

Each Start-up of a High-Voltage synchronous motors passes through multiple jumps in the currents and torques of the motor, with voltage deviation, heating of the motor and losses, which reduce the technical life of the units and the equipment as a whole [12, 13]. Therefore, eliminating or minimizing the negative factors affecting the electric pumping units during startup is a very urgent issue that needs to be research and optimized.

\section{Simulation result}

With the development of power electronics, various types of semiconductor converters with different functions and capabilities became available, such as current source inverters and voltage regulators, serving only for the soft Start-up of High-Voltage AC motors [4, 14]. The elimination of negative factors during Start-up can be achieved using soft starters, since they are cheaper than the inverter by almost two to three times, and are good for alternating soft start of several electric motors [8]. For this purpose, in this work, we simulated the transient process with direct and soft Start-up of motor. The main program for modeling was adopted by the MATLAB/Simulink. With this program may be constructed the diagrams of transient process of starting regime of the High-Voltage synchronous motor [9]. The results of simulation shown in Figures 3 and 4. 

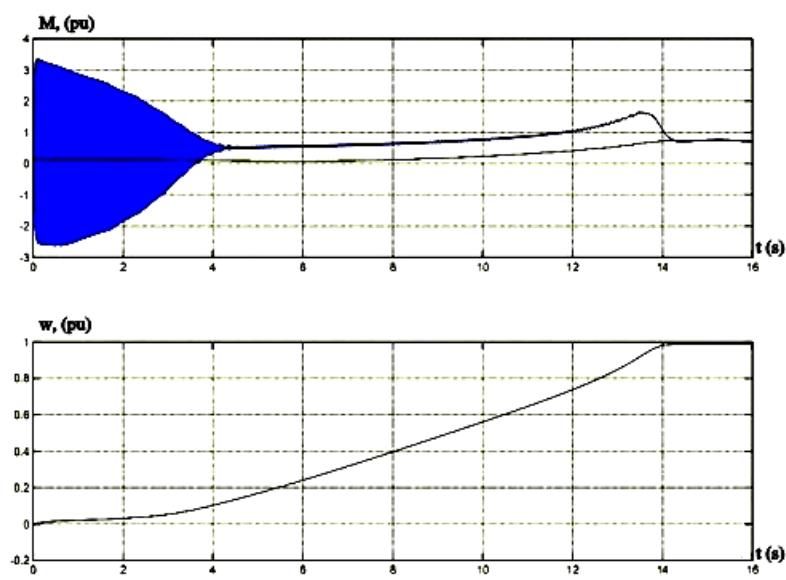

Fig. 3.Transient diagrams for direct Start-up of motor series VDS2-325/69-16.
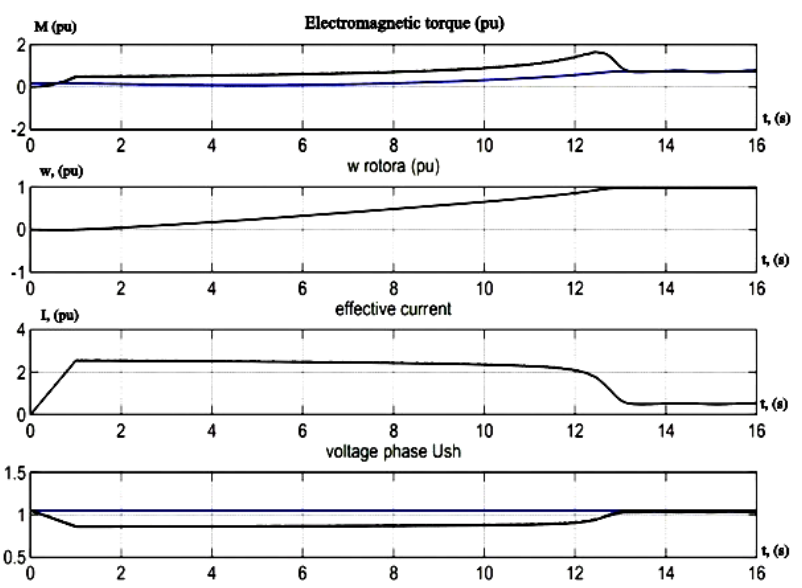

Fig. 4.Transient diagrams for soft start of motor series VDS2325/69-16.

As the simulation results (see Figure 4) show, using the soft starter provides fairly favorable conditions for transient processes, namely, it limits the values of starting current and jumps in the amplitudes of the oscillations of the electromagnetic torques of motor. In addition, modern soft starters provide the following advantages:

- significantly reduces dynamic loads on the bearings of the electric motor;

- improve operating conditions of electrical equipment;

- significantly reduces current, power losses and voltage deviations in the network when starting the electric motor;

- increase the numbers of permissible starts;

- having possibility the start of electric motors from sources with limited power;

- improving the reliability and service life of electric equipment.

\section{Conclusion}

As a result of the study of transients of the electric drive of the pumping units of the ANS-1 irrigation pumping station, it was shown that to optimize starting conditions, it is sufficient to use a soft starter, which are cheaper and can be used for turning on several electric motors in turn. The results of computer simulation showed that the negative effects of currents and moments can be reduced with the help of soft starters.

\section{References}

[1] A.N. Goryunov, Tekhnologicheskie osobennosti rezhimo $\mathrm{v}$ raboty nasosnykh stantsiy pervogo pod"ema na stantsiyakh vodopodgotovki [Technological features of the operating modes of pumping stations of the first lift at water treatment plants], NOVYE TEKhNOLOGII 6, Moscow (2010)

[2] S.T. Dadabaev, Obzor i otsenka sposobov upravleniya nasosnymi ustanovkami [Overview and evaluation of methods of control pump installation], Elektrooborudovanie: ekspluatatsiya i remont 12, 28-30 (2013) (in Russian)

[3] S.T. Dadabaev, Razrabotka matematicheskoy modeli system yregulirovaniya nasosnykh agregatov orositel'noy stantsii pervogo pod"ema [Development of a mathematical model for the control system of pumping units of the first-stage irrigation plant], Izvestiya Tul'skogogo sudarstvennogo universiteta, Tekhnicheskie nauki 9-1, 532-536 (2017)

[4] D.S. Tolibjonovich, T.M. Islomovna, M.D. Saidulloevna, Modeling of starting transition processes of asynchronous motors with reduced voltage of the supply network, European Journal of Electrical Engineering 22, 1, 23-28 (2020) DOI: 10.18280/ejee. 220103

[5] V.N. Larionov, A.G. Kalinin, Energoeffektivnost' i energosberezhenie $\mathrm{V}$ elektroprivodakh S ventilyatornoinagruzkoi [Energy efficiency and energy saving in electric drives with fan load] (Cheboksary, Izd-vo. Chuvash. Un-ta, 2012) 146 (in Russian)

[6] B. Wu, M. Narimani, High-Power converters and $A C$ drives, 2rd edition (Wiley-IEEE Press, 2017)

[7] S. Chapman, Electric Machinery Fundamentals, 5th Edition (Mcgraw Hill Higher Education, 2011)

[8] S.T. Dadabaev, Optimization of Starting Modes of High-Voltage Electric Drives of Irrigation Pumping Station in Hot Climate, Russian Electromechanics 2, 86-91 (2018) DOI: 10.17213/0136-3360-2018-2-86-91 (in Russian)

[9] S.T. Dadabaev, Simulation of Soft Start of Synchronous Electric Drives, CAD/EDA, Modeling and Simulation in Modern Electronics: collection of scientific papers of the III International Scientific and Practical Conference, 140-145 (2019) DOI: 10.30987/conferencearticle_5e0282116891e4.1808 4453

[10] E.I. Gracheva, O.V. Naumov, Estimation of Power Losses in Electric Devices of the Electrotechnical Complex, International Conference on Industrial 
Engineering, Applications and Manufacturing (ICIEAM) 6 (2019)

[11] P.C. Krause, et al., Analysis of Electric Machinery and Drive Systems, 3rd edition (Wiley-IEEE Press, 2013)

[12] J. Nevelsteen, H. Aragon, Starting of Large Motors - Methods and Economics, IEEE Transactions on Industry Applications 25, 6, 1012-1018 (November/December 1989)

[13] P.C. Sen, Principle of Electric Machines and Power Electronics, 3rd Edition (Wiley, 2013)

[14] V.M. Perelmuter, Electrotechnikal systems, Simulation with Simulink and SimPowerSystems (CRC Press, 2013) 